\title{
G0310505
}

\section{画像相関法による变位場測定データを用いた $\mathrm{J}$ 稘分評価}

\author{
山根弘人 ${ }^{* 1}$, 米山聡 ${ }^{* 2}$, 有川秀一 ${ }^{* 2}$, 渡部康明 ${ }^{* 3}$, 浅井竜彦 ${ }^{* 3}$, 塩川国夫 ${ }^{* 3}$, 山下満男 ${ }^{* 3}$
}

\section{J-integral Evaluation from Measured Displacement Fields Using Digital Image Correlation}

\author{
Hiroto YAMANE ${ }^{* 1}$, Satoru YONEYAMA ${ }^{* 2}$, Shuichi ARIKAWA ${ }^{* 2}$, Yasuaki WATANABE ${ }^{* 3}$, \\ Tatsuhiko $\mathrm{ASAI}^{* 3}$, Kunio SHIOKAWA ${ }^{* 3}$ and Mitsuo YAMASHITA ${ }^{* 3}$ \\ ${ }^{* 1,}{ }^{* 2}$ Department of Mechanical Engineering, Aoyama Gakuin University, Sagamihara 252-5258, Japan \\ ${ }^{* 3}$ Fundamental Technology Research Center, Fuji Electric Co., Ltd., Tokyo191-8502
}

In this paper, a method for evaluating the J-integral for the displacement field obtained by digital image correlation without modeling the stress strain relationship is proposed. First, the displacement gradient and strain are determined from the displacements using a local least-squares method on the domain of integration. Next, the stress components are determined from the strain using the Hencky's equation and material properties. Finally, the J-integral value is determined by the numerical integration on the domain of integration. The usefulness of this evaluation method is verified by applying this method to the displacement field obtained from the elastic-plastic finite element analysis and digital image correlation.

Key Words : Elasto-Plasticity, Fracture Mechanics, Digital Image Correlation, J-integral

\section{1. 粕}

航空機産業や原子力分野などにおいて, 製造時や供与中に発生した欠陥を対象として, 破壊力学的な構造物の 健全性評価が行われている. き裂や欠陥を有する材料の破壊現象を定量的に扱うパラメータとしては応力拡大係 数 $K, \mathrm{~J}$ 積分, き裂開口変位 $\delta$ などが用いられる(1). 物体の形状・寸法・荷重条件などが異なっていても，このパ ラメータの值が同一ならば，同様の破壊現象が起きると予測する事が可能である.このような破壊力学パラメー 夕の評価は, 一般的にはハンドブッグ(1)を参照とするか, もしくは有限要素解析(2)により行われる事が多いが, 実 機では対象の形状や境界条件が複雑な場合が多い事から，これらの手法で得られた值の信頼性が問題となり，こ のため実機において予期しない破壊が見られる.

また近年では, 画像相関法(DIC)などの光学的測定を用いてき裂先端近傍の変位分布を容易に所得する事が可能 になっている(3). したがって，境界条件が取得できていなくても，き裂や欠陥を有する製品において光学的な測 定法を用いて取得した変位分布から破壊挙動を評価する事が可能であると考えられる. 光学的測定法から得られ た変位場から応力拡大係数 $K$ や積分の值を求める方法についてはこれまで多くの研究(4-6)がなされている. しか し，これらの手法において，ひずみから応力を算出する際には，応力ひずみ関係をモデル化した構成式を用いて ひずみから応力を算出しており，このモデル化する際の近似の誤差が J 積分の值に影響すると考えられる.

本研究ではDICから得られたき裂先端近傍の変位分布から応力ひずみ関係をモデル化せずに実験から得られた 応力ひずみ線図から直接的にひずみから応力を決定する.これにより，応力ひずみ関係を近似する際の誤差の影 響がなくなり，J積分の評価をより精度良く行う事が可能になると考えられる. 本手法を弾塑性有限要素解析と DICから得られた変位場に対してそれぞれ適用し, 有効性を検証する. この手法を用いる事により, 境界条件が 得られていない場合においても，き裂先端近傍の変位場から容易に，精度良く $\mathrm{J}$ 積分を評価する事ができる.

\footnotetext{
*1 青山学院大学大学院 (广 252-5258 神奈川県相模原市中央区淵野辺 5-10-1)

*2 正員, 青山学院大学 ( ₹ 252-5258 神奈川県相模原市中央区淵野辺 5-10-1)

*3 富士電機株式会社 ( ₹ 191-8502 東京都日野市富士町 1 番地)

E-mail: c5613136@aoyama.jp
}

[No.14-1] 日本機械学会 2014 年度年次大会講演論文集 [2014.9.7-10, 東京] 


\section{J程分鲆価方法}

\section{$2 \cdot 1 \mathrm{~J}$ 積分}

$\mathrm{J}$ 積分は線形弹性体ではき裂進展に伴うポテンシャルエネルギーの解放率であり, 非線形弾性体では破壊力学 パラメータとして，き裂先端近傍の応力場を表す．また，全ひずみ理論に従う弾塑性体においても，除荷がない 時はその力学的な挙動は非線形弾性体と同様のように表せる(7). 米山ら ${ }^{(5)}$ は画像相関法から得られたき裂先端近傍 の変位分布から $\mathrm{J}$ 積分を評価する際に経路積分, 領域積分の両手法を用いて評価を行っている. この結果から領 域積分を用いる事によって, 実験データで評価する際の変位の測定誤差による $\mathrm{J}$ 積分值の誤差を軽減できる事が 明らかになっている．このため，本研究においても領域積分を用いて評価を行う．J積分は次式で定義できる.

$J=\int_{\mathrm{A}}\left(W \frac{\partial q}{\partial x_{i}}-\sigma_{i j} \frac{\partial u_{i}}{\partial x} \frac{\partial q}{\partial x_{j}}\right) d \mathrm{~A} \quad(i, j=x, y)$

式(1)において A は図 1 に示すようなき裂先端周りの 2 つ境界 $\Gamma_{0}$ と $\Gamma_{1}$ とき裂面で囲まれた領域であり，Wはひ ずみエネルギ一密度, $u_{i}$ は領域上の変位成分を示している. また $q$ は外側の境界 $\Gamma_{0}$ 上で 0 , 内側の境界 $\Gamma_{1}$ 上で 1 となる任意の関数である. q は次式を用いる.

$q=\frac{r_{\text {out }}^{2}-\left\{\left(x-x_{0}\right)^{2}+\left(y-y_{0}\right)^{2}\right\}}{r_{\text {out }}^{2}-r_{\text {in }}^{2}}$

$r_{\text {out }} ， r_{\text {in }}$ はそれぞれ積分領域の外径と内径であり， $x_{0}, y_{0}$ はき裂先端の座標である. 線形弾性の場合, この変換 は正確であり，荷重が比例的，つまり除荷が発生しなければ非線形の場合でも正確である．また，J積分值が積 分領域に依存せず，領域独立性を持つ。

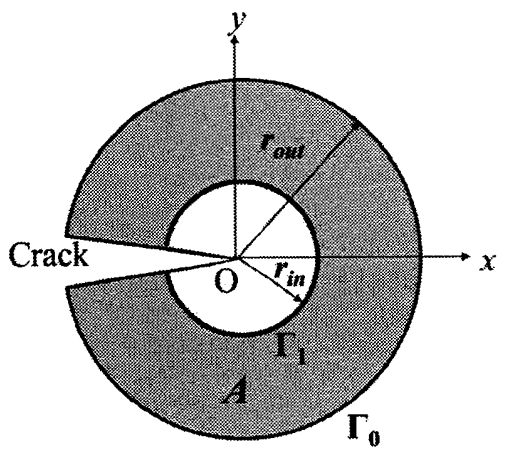

Fig. 1 Domain of integral

\section{$2 \cdot 2$ 評価手順}

DIC などの変位測定法によりき裂先端近傍の変位場が得られていると考える. 得られた変位場から変位勾配を 求めるが, その方法としては, 局所最小二乗法を利用する. さらに, 求めた変位勾配から応力を算出する. 本研 究では変位場から評価を行う事から, 応力やひずみの履歴は考慮しない. このため, 全ひずみ理論に基づくもの とすると，弾塑性体における応力ひずみ関係は次式で表す事ができる(8).

$e_{i j}=\left(\phi+\frac{1}{2 G}\right) s_{i j}$

ここで, $G$ はせん断弾性係数, $e_{i j}, s_{i j}$ は偏差ひずみと偏差応力, また, $\phi は$ 加工硬化法則に依存するパラメータで あり，次式で表される.

$\phi=\frac{3 \varepsilon_{e}^{(\mathrm{p})}}{2 \sigma_{e}}$ 
上式において， $\varepsilon_{\mathrm{e}}^{(p)}$ と $\sigma_{\mathrm{e}}$ は相当塑性ひずみと相当応力である. 草柳ら ${ }^{(6)}$ はひずみから応力を算出する際，式(4)に おける中を Ramberg-Osgood のモデルから求め, 応力ひずみ関係をモデル化する事によりひずみから応力を求めて いる. しかし，モデル化する際の近似の差が $\mathrm{J}$ 積分值に影響すると考えられる.このため，実験データから得ら れた $\mathrm{J}$ 積分值について精度良く評価するために, 本研究では応力ひずみ関係をモデル化せずに応力を算出し, $\mathrm{J}$

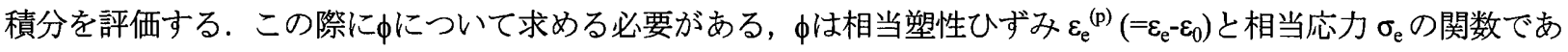
る事から，単軸の引張試験から得られた応力ひずみ関係から直接的に中を求める事ができる.また，ひずみエネ ルギー密度 $W$ は $W=\int_{0}^{\varepsilon_{i j}} \sigma_{i j} d \varepsilon_{i j}$ である事から

$W=\frac{1}{2 E}\left\{\sigma_{e}^{2}+(1-2 v)\left(\sigma_{x} \sigma_{y}-\tau_{x y}^{2}\right)\right\}+\frac{2}{3} \sigma_{e}^{2} \phi-\int_{0}^{\sigma_{e}} \varepsilon_{e}^{(p)} d \sigma_{e}$

となる．上式の積分部分に関しては事前に単軸の応力ひずみ線図の各応力值をから求めておいた值を用いる．実 際にひずみエネルギ一密度を算出する際には，直線補間を利用する事により積分計算の部分を求める. そして, 各々の過程で得られた值を $\mathrm{J}$ 積分の領域積分の定義式である式 (1)に代入する事により $\mathrm{J}$ 積分値を算出する.

\section{3. 弾檠性有限要索解析から得られた变位場に対する逽用}

提案する手法の有効性を検証するために, 弾塑性有限要素解析から得られたき裂先端近傍の変位分布に対し, 本手法を適用した. モデルの形状は図 2(a)に示す通りであり，き裂長さは $a=25 \mathrm{~mm}$ としている. 要素数は 9060 , 要素タイプには 4 節点平面応力要素を用いており, 材料としては純アルミニウムの焼きなまし材(A1050-O)を模擬 している. 図 2(b)に純アルミ二ウムの焼きなまし材（A1050-O）において, 単軸の引張試験から得られた真応力真ひずみ線図と応力ひずみ関倸をモデル化した近似曲線を示す．モデルに対して引張試験から得られた材料特性 を与えて解析を行い，き裂先端近傍の変位分布 $(12 \mathrm{~mm} \times 12 \mathrm{~mm})$ を $0.2 \mathrm{~mm}$ 間隔で抽出し，種々の荷重において積分 領域内径については $r_{\mathrm{in}}=2.0 \mathrm{~mm}$ で固定し, 積分領域外径を $r_{\text {out }}=2.5 \sim 5.0 \mathrm{~mm}$ で変化させ, 複数の積分領域で算出し た. 設定した積分領域上の変位勾配の值は最小二乗法を利用して算出したが, その際のデータ範囲は半径 $0.8 \mathrm{~mm}$ の円形とした. その後, 式(3)から态力成分を, 式(5)からひずみエネルギー密度を算出し, 得られた值を式(1)に代 入して $\mathrm{J}$ 積分值を評価した．また，本解析においては本手法の有効性を検証するために応力ひずみ関係をモデル 化した手法とモデル化しない手法でそれぞれ J積分值を算出し，両手法を比較する.

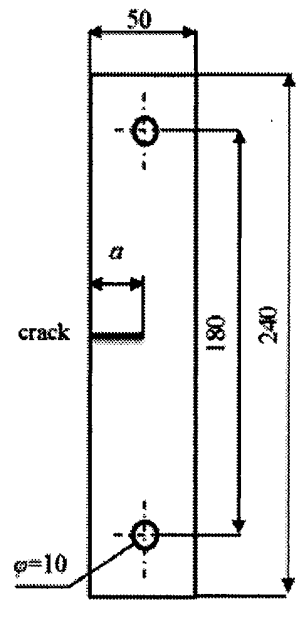

(a)

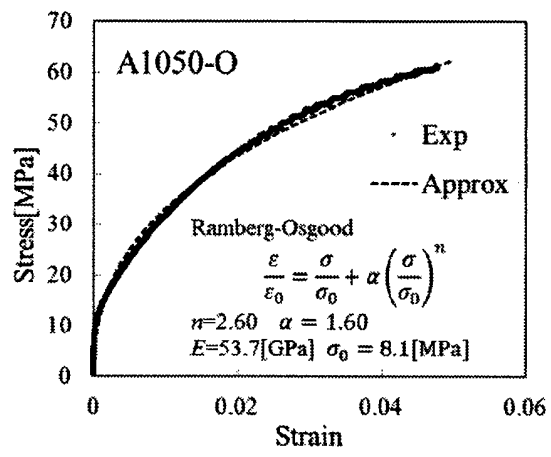

(b)

Fig. 2 (a) Specimen for simulation and experiment and (b) stress/strain response of homogenous material 


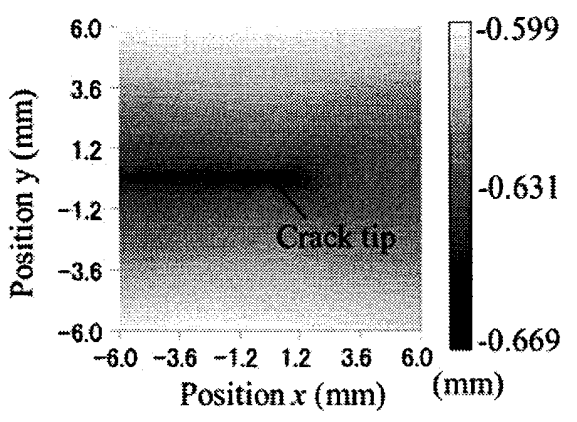

(a)

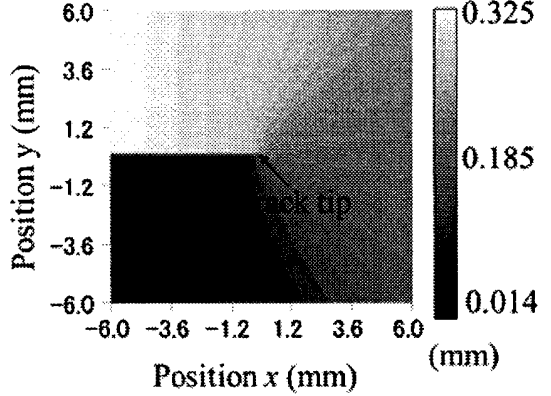

(b)

Fig. 3 Displacement distribution obtained by finite element analysis $(a=25 \mathrm{~mm}):(\mathrm{a}) u_{x} ;$ (b) $u_{y}(P=1736 \mathrm{~N})$

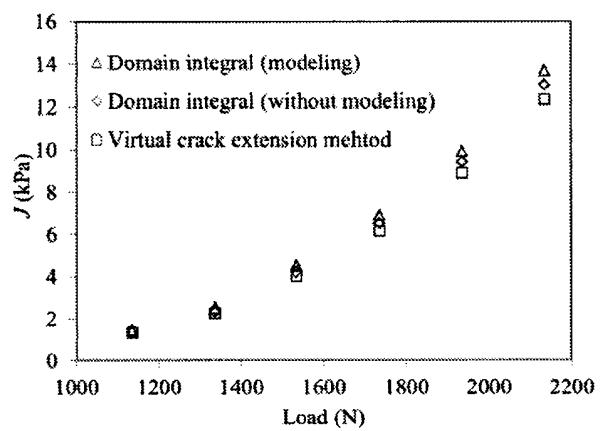

(a)

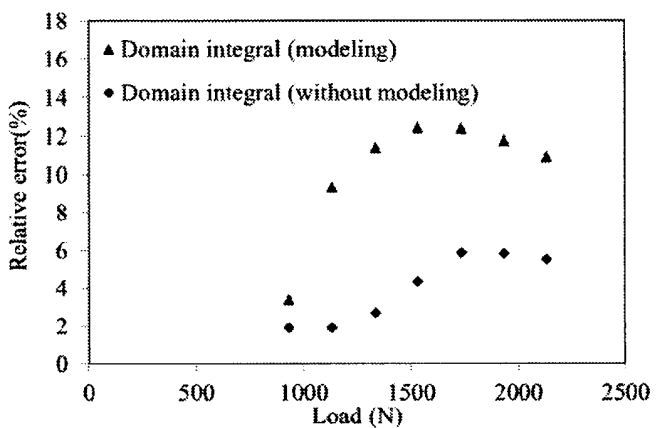

(b)

Fig. 4 (a) $J$ value obtained by various methods and (b) relative error

図 3 は有限要素解析から得られたき裂先端近傍の変位分布である. 変位分布において，き裂先端は座標軸の中 心であり，き裂面はき裂先端の左側に位置している．また，図 4 は弾塑性有限要素解析から得られた変位場から 本手法を用いて $\mathrm{J}$ 積分值を評価した結果である，さらに，図 4(a)は本手法において，応力ひずみ関係をモデル化 した手法とモデル化しない手法で各々算出した $\mathrm{J}$ 積分值と, 本手法とは別に汎用有限要素ソフトウェアにより仮 想き裂進展法（Virtual Crack Extension Method，以降 VCEM）を用いて得られた J 積分値を比較した結果である. この結果を見ると本手法と仮想き裂進展法から算出した $\mathrm{J}$ 積分值がほぼ一致しており，本手法を用いて $\mathrm{J}$ 積分を 評価する事できると考えられる．また，図4(b)はVCEM を用いて得られた J 積分值を参照值として，モデル化す る手法とモデル化をしない手法において，それぞれ VCEM から算出した J 積分值に対する相対誤差を示したもの である.この結果を見ても，モデル化する手法から算出した $\mathrm{J}$ 積分值は最大 $12 \%$ 程度誤差があるのに対し，モデ ル化しない手法から算出した $\mathrm{J}$ 積分值は誤差が最大 $6 \%$ 程度となっており, この結果からも, 応力ひずみ関係をモ デル化しない手法の方がより $\mathrm{J}$ 積分值を精度よく評価する事が可能である事がわかる.

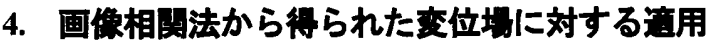

次に本手法を DIC から得られた変位場に対して適用した．供試材および試験片形状については図 2 と同様に A1050-O を用いている. 本実験では画像相関法により変位測定を行うため, 試験片表面に白色および黒色スプレ

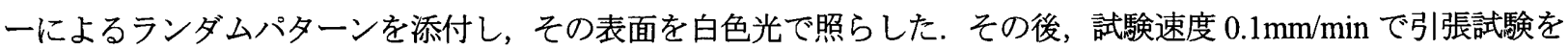
行い，負荷前後のランダムパターンの変動を単色 8 ビット CCD カメラ(1024×768 画素)により $1 \mathrm{frame} / \mathrm{s}$ の速度で 撮影した．実寸法上の $1 \mathrm{~mm}$ は画像上で約 28 画素とした．また画像データと同時にデータロガーTDS - 530 を用 いて 1 秒後ごとに荷重を記録した. 得られたき裂先端近傍の差画像から変位を算出する際の相関演算における計 算領域に大きさについては, $31 \times 31$ 画素とし, き裂先端を中心とした $12 \times 12 \mathrm{~mm}$ の領域における変位分布を $0.2 \mathrm{~mm}$ 間隔で抽出し，得られた変位分布から本手法を用いて $\mathrm{J}$ 積分を評価した 


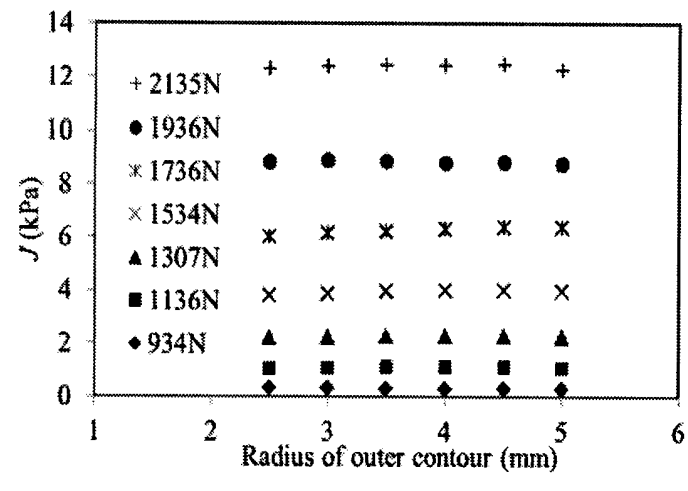

(a)

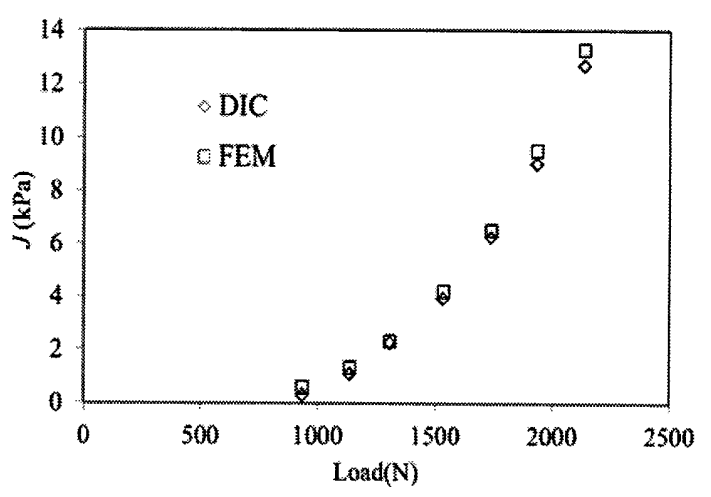

(b)

Fig. 5 (a) $J$ values for various integral domains; (b) Comparison of $J$ values obtained by DIC and FEM

図 5 はDIC から得られた変位分布から本手法を用いて算出した J 積分值である. 図 5(a)は種々の荷重において 複数の積分領域で $\mathrm{J}$ 積分を評価した結果となっている。この結果から $\mathrm{J}$ 積分值が積分領域に依存しておらず，領 域独立性を示している事がわかる. また, 図 5(b)はDIC と弾塑性有限要素解析から得られた変位場に対してそれ ぞれ本手法を適用し，得られた $\mathrm{J}$ 積分值を比較した結果である，両者を比較すると $\mathrm{J}$ 積分值がほぼ一致している 事がわかる．以上の事から，DICから得られた変位場に対して本手法を用いて J 積分を評価する事が可能である と考えられる.

\section{5. 結 贯}

弾塑性体の応力ひずみ関係をモデル化せずに $\mathrm{J}$ 積分を求める方法を提案した．この方法を用いる事により，モ デル化する手法の際に生じる, 応力ひずみ関係の近似の誤差がなくなり，より実験時の $\mathrm{J}$ 積分の評価というのが 正確になる. また, 本手法を弾塑性有限要素解析と DIC から得られた変位場に対して適用してその妥当性を検証 し, 得られた結果より, き裂先端近傍の変位分布から $\mathrm{J}$ 積分を評価する事が可能である事を示した. これにより, 境界条件が得られていない場合でも容易に測定した変位場から $\mathrm{J}$ 積分を評価する事が出来るため，本手法を用い て簡便に構造部品の実験的な破壊挙動の評価を行う事ができると考えられる.

\section{6. 考文献}

（1）小林英男，“構造健全性評価ハンドブック”，共立出版 (2005).

(2) 三好俊郎, 白鳥正樹, “有限要素法によるJ 積分の評価に関する研究”, 日本機械学会論文集 A 編, Vol. 49, No. 437 (1983), pp. 3-9.

(3) 米山聡，“デジタル画像相関法を用いた変位ひずみ分布測定, 非破壊検查”，Vol. 57, No. 7 (2010), pp. 306-310.

(4) Yoneyama, S., Ogawa, T. and Kobayashi, Y., "Evaluating Mixed-mode Stress Intensity Factors from Full-field Displacement Fields Obtained by Optical Methods", Eng. Fract. Mech., Vol. 74, No. 9 (2007), pp. 1399-1412.

(5) Yoneyama, S., Arikawa, S., Kusayanagi, S. and Hazumi, K., "Evaluating J-integral from Displacement Fields Measured by Digital Image Correlation", Strain, Vol. 50, No. 2 (2013), pp. 147-160.

（6）草柳悟，米山聡，有川秀一，渡部康明，塩川国夫，“き裂近傍変位場測定デー夕を用いた $\mathrm{J}$ 積分評価手順”，実験力 学, Vol. 12, No. 3 (2012), pp. 227-234.

(7) Rice, J.R., "A Path Independent Integral and the Approximate Analysis of Strain Concentration by Notches and Cracks", Journal of Applied Mechanics, Vol. 35 (1968), pp. 379-386.

（8）国尾武, “固体力学の基礎”, 培風館 (1977). 